\title{
Dávidovics Anna
}

\author{
Pécsi Tudományegyetem \\ Általános Orvostudományi Kar \\ Egészségügyi Nyelvi és Kommunikációs Intézet
}

\section{Szaknyelvoktatás és gamifikáció}

\author{
https://doi.org/10.48040/PL.2021.2
}

\begin{abstract}
A Pécsi Tudományegyetem Orvostudományi Kara nagy népszerüségnek örvend mind a magyar, mind pedig a külföldi hallgatók körében, utóbbiak a világ számos országából érkeznek az intézménybe. A hallgatók nemzetiségtöl függetlenül komoly elvárásokkal kezdik meg tanulmányaikat, támaszkodva a tanulásról és tanitásról alkotott, korábbi tapasztalataikon alapuló elképzeléseikre. Ezek a tapasztalatok igen változatosak lehetnek, tekintve, hogy a külföldi hallgatói csoportokban számos különbözö náció és kultúra találkozik. A szaknyelvoktatóknak igy sokszor nem egyszerü a feladata, hogy a lehetö leghatékonyabb módszereket válasszák ki és alkalmazzák akár a külföldi, akár a magyar hallgatói csoportokban. Ennek a tanulmánynak a célja két online kérdöiv eredményeinek bemutatása és összehasonlitása, melyeknek a célja a külföldi és magyar orvostanhallgatók által leghatékonyabbnak itélt módszerek összegyüjtése és értékelése volt. A két hallgatói csoport választásai között nem mutatkoztak éles különbségek, ellenben számos kérdésben hasonló, szinte megegyezö válaszok érkeztek. Kiemelkedöen magas volt a gamifikáció pozitiv megitélése és támogatása a hallgatók körében, ezért elmondható, hogy a szaknyelvórák játékositása pozitív hatással lehet a tanulási folyamatra.
\end{abstract}

Kulcsszavak: gamifikáció, motiváció, szaknyelvoktatás, magyar orvostanhallgatók, külföldi orvostanhallgatók

\section{Bevezetés}

Köszönhetően a globalizációs folyamatoknak, a külföldi hallgatók száma ugrásszerüen megnött világszerte a 21. században. A 2019-es OECD statisztikák szerint 2017-ben már több, mint 5 millió hallgató folytatta tanulmányait egy számára idegen ország felsőoktatási intézményében (OECD, 2019). Ez azonban nem az egyetlen olyan folyamat, amely változást indított el az oktatásban.

A digitális technológiák megjelenése és fejlödése is egyre nagyobb hatást gyakorolt az oktatás különbözö színtereire, ahogy az igény is megnövekedett a használatukra. Azok a hallgatók, akik jelenleg tanulmányaikat a felsőoktatási intézményekben folytatják, nagyban különböznek a korábbi generációktól. Nekik a különbözö technikai újítások teljesen természetesek, egy olyan világba születtek és nőttek bele, ahol ezek az eszközök már rendelkezésre álltak, így a tanulási stílusuk és igényeik is 
más jellegüek, mint a korábbi hallgatói generációé (Kiryakova et al., 2014). Annak érdekében, hogy a tanulási folyamat a lehetö leghatékonyabb legyen, a tanárnak célszerü kihasználnia és alkalmaznia ezeket a technológiákat az órákon is (Németh - Csongor, 2019).

A külföldi hallgatók létszámának növekedése a magyar egyetemeken is megfigyelhető. A négy orvosi egyetem különösen népszerü választás a más országokból érkező diákok körében (Pozsgai et al., 2012; Németh - Pozsgai, 2018; Marek - Németh, 2020). Ahogy az a Pécsi Tudományegyetem honlapján is látható (UP, 2020), 2020 júniusában közel 4500 külföldi diáknak volt aktív hallgatói státusza az egyetem valamelyik karán. Közülük 1911-en az Általános Orvostudományi Karon folytatták tanulmányaikat, ahogy ezt a kari honlapon közzétett lista is mutatja (UPMS, 2020). Ez a szám azért is érdekes, mert így a külföldi hallgatók aránya eléri a közel 60\%-ot az Általános Orvostudományi Karon, a magyar hallgatók aránya pedig mindösszesen $40 \%$ körül mozog.

\section{Szaknyelvoktatás a Pécsi Tudományegyetem Általános Orvostudományi Karán}

A Pécsi Tudományegyetem Általános Orvostudományi Karán három különböző programon tanulhatnak a hallgatók (általános orvos, fogász és gyógyszerész). Ezek a programok három nyelven is rendelkezésre állnak: magyar, angol és német. A vegyes nációjú- és kultúrájú csoportok leginkább az angol programon figyelhetőek meg, a német és magyar programon többnyire homogének a csoportok (a hallgatók többsége német, illetve magyar). A külföldi és a magyar hallgatóknak lehetőségük van részt venni néhány közös kurzuson is azzal a céllal, hogy egymást segítsék, valamint fejlesszék interkulturális készségeiket is (Németh - Kajos, 2014; Németh Rébék-Nagy, 2015).

Mindegyik programon és mindhárom nyelven választhatnak a hallgatók szaknyelvi kurzusokat, melyeknek egyik célja többek között a tanulók anamnézis-felvételre történő felkészítése az adott nyelven. A magyar hallgatóknak orvosi angol kurzusok állnak rendelkezésükre, a külföldi hallgatók pedig magyar orvosi szaknyelvi órákon vehetnek részt. Mivel a külföldi hallgatók között elenyésző számban vannak csak olyanok, akik már rendelkeznek magyar nyelvismerettel az egyetemre érkezésük elött, számukra a magyar szaknyelv elsajátítása nem kis kihívást jelent.

A magyar orvosi szaknyelvi órákat a hallgatók 4-6 féléven keresztül tanulhatják, egy-egy szemeszterben heti 4 órában. A nyelvi órák elsődleges célja a külföldi hallgatók felkészítése a képzésük 5 . félévében esedékes orvosi propedeutika tantárgyra, amelynek során alapvetően szükséges, hogy a 
hallgatók tudjanak kommunikálni a magyar betegekkel (Csongor et al., 2018).

\section{Gamifikáció és a „digitális bennszülöttek”}

A magyar és a külföldi hallgatók között alapvető különbségek vannak a náció és kulturális háttér szempontjából, viszont számos hasonlatosság is megfigyelhető a két csoport között. A hallgatók nagy része ugyanahhoz a generációhoz tartozik, ők az úgynevezett „digitális bennszülöttek”, akik a digitalizáció és modern technológiák világába születtek bele, és a hordozható eszközökön nőttek fel (Prensky, 2001; Kovács - Várallyai, 2018).

A gamifikáció játékszerü elemek és eszközök felhasználását jelenti egy nem játékszerü környezetben (például tanórán). Elsődleges célja a résztvevők minél sikeresebb bevonása és motiválása a célok elérése érdekében (Deterding et al, 2011; Korkealehto - Siklander, 2018). A gamifikáció oktatás során való felhasználása azonban nem pusztán a résztvevők szórakoztatását szolgálja, hanem interaktív, játékszerü elemek felhasználásával kívánja elérni az elöre meghatározott célt (Kiryakova et al., 2014). Az interaktív jelleg és a hallgatók aktív bevonása pozitív hatással lehet a tanulási folyamatra, ellentétben a hagyományosabb, frontális módszerekkel. A gamifikáció egyik nagy előnye, hogy a számítógépes játékokhoz hasonlóan lelkes és aktív részvételt képes generálni. A hallgatók tudatos bevonása a saját tanulásuk folyamatába nagymértékben növeli a motivációjukat, hosszú távon sikeresebbé téve ezzel a tanulást. A gamifikáció másik alapvető fontosságú része a (legtöbbször azonnali) visszajelzés (feedback). Ez sokat segíthet a hallgatóknak a tanulás során, a pozitív visszajelzés és sikerélmény pedig növelheti motivációjukat, ösztönözheti őket abban, hogy továbbra is aktívan vegyenek részt a feladatokban (Kovács - Várallyai, 2018). A gamifikáció nyújtotta lehetőségek kiszélesedtek azzal, hogy az egyes applikációk már mobil készülékeken is elérhetővé váltak (Kayımbaşığlu et al., 2016). Ezeknek a technológiáknak a felhasználása egyre nagyobb szerepet kap a nyelvoktatás során is (Polonyi - Abari, 2017).

\section{Módszerek}

Jelen tanulmány egy longitudinális kutatás részét képezi, melynek elsődleges célja a külföldi hallgatók tanulásról és tanításról alkotott véleményének vizsgálata, valamint az eredmények szintetizálása az oktatásban való alkalmazáshoz. A kutatás több módszerre is támaszkodik, az első fázisban elsősorban online kérdőívek segítségével került sor az adatgyüjtésre magyar, valamint külföldi orvostanhallgatók bevonásával a Pécsi Tudományegyetem 
Általános Orvostudományi Karán, a 2018/19-es tanév második szemeszterében.

A kérdöívbe olyan külföldi, valamint magyar hallgatók lettek bevonva, akik az adott szemeszterben az Egészségügyi Nyelvi és Kommunikációs Intézet által meghirdetett kurzusok valamelyikére jártak. Mindkét hallgatói csoport szaknyelvi órákon vett részt, az angol programon tanuló külföldi hallgatók magyar, a magyar hallgatók angol orvosi szaknyelvet tanultak. A kutatás kényelmi mintavétellel zajlott, azoknak a hallgatóknak a részvételével, akiket az adott időpontban a legkönnyebben el lehetett érni.

\section{Résztvevök}

A kérdőíveket összesen 226 külföldi és magyar hallgató töltötte ki. Közülük 133-an az angol nyelvü, 93-an pedig a magyar képzésben folytatták tanulmányaikat. A külföldi hallgatók 27 különböző nemzetiséghez tartoztak (a legnagyobb számban norvégok, irániak és dél-koreaiak voltak). A magyar csoportok nemzetiség szempontjából homogénnek tekinthetőek. Az így keletkező kulturális és nacionális különbségek mellett még egy érdekes variáns jelentkezett a két csoport beszélt nyelvekkel kapcsolatos válaszaiban. Az angol, mint második beszélt nyelv szinte kivétel nélkül minden hallgató válaszaiban megjelent, viszont a magyar társaikkal ellentétben a külföldi hallgatók három, esetenként négy másik nyelvet is felsoroltak az általuk beszélt nyelvek között. Ez a szám a magyar hallgatók válaszaiban kettőre vagy háromra korlátozódott. Ahogy az 1. táblázat is mutatja, a felmérésben résztvevők között mindkét csoportban több volt a nö, mint a férfi, életkor tekintetében pedig a legtöbb hallgató 21 és 25 év között volt.

1. táblázat. A külföldi és magyar hallgatók nem és életkor szerint (fö)

\begin{tabular}{cccc}
\hline Nem & Nö & Férfi & Egyéb \\
\hline Külföldi & 77 & 55 & 1 \\
\hline Magyar & 57 & 36 & - \\
\hline Életkor & $>20$ & $21-25$ & $26-35$ \\
\hline Külföldi & 7 & 118 & 8 \\
\hline Magyar & 3 & 87 & 3 \\
\hline
\end{tabular}


A hallgatók többsége az általános orvosi képzésben folytatta tanulmányait, ahogyan ezt a 2. táblázat is mutatja, a többség első- vagy másodéves volt, amikor a felmérés készült.

2. táblázat. A külföldi és magyar hallgatók képzés és évfolyam szerint (fö)

\begin{tabular}{lcccccc}
\hline Képzés & Általános orvos & Fogorvos & Gyógyszerész & & \\
\hline Külföldi & 116 & 11 & 6 & & \\
\hline Magyar & 83 & 10 & - & & \\
\hline Évfolyam & I. & II. & III. & IV. & V. \\
\hline Külföldi & 36 & 81 & 12 & 4 & - \\
\hline Magyar & 8 & 42 & 18 & 10 & 15 \\
\hline
\end{tabular}

\section{Eszközök}

A hallgatók a kérdőíveket a Google Forms online felületén érhették el és tölthették ki. A kérdőív a Pécsi Tudományegyetem tanulmányi rendszerén keresztül, e-mailen jutott el hozzájuk. A felmérés során a hallgatók összesen 39 kérdésre és állításra válaszolhattak, illetve fejthették ki a véleményüket. A kérdőív első része a hallgatók nemzetiségére, életkorára, nemére, szakjára és évfolyamára kérdezett rá, valamint az általuk beszélt nyelveket sorolhatták fel. A kérdések és állítások többi része négy csoportba lett osztva, amelyek kitértek a tanulási és tanítási folyamatra, a különböző órákon belüli munkaformákra, módszerekre és feladatokra is. Az utolsó szekció kiemelten foglalkozott a gamifikációval és különböző digitális eszközök használatával a tanórán és azon kívül is.

A hallgatók véleményüket öt pontos Likert-skála segítségével jelezhették, amely a „teljes mértékben egyetértek”-től az „egyáltalán nem értek egyet”-ig terjedt. Egy „semleges” lehetőség is a válaszadók rendelkezésére állt abban az esetben, ha nem volt egyértelmü preferenciájuk az adott kérdéssel kapcsolatban. Az egyes szekciók utolsó kérdése mindig nyitott volt, így a hallgatók szabadon, saját szavaikkal fejthették ki a véleményüket.

\section{Eredmények}

Érdekes módon a magyar és a külföldi hallgatók választása és preferenciái a legtöbb esetben meglehetősen hasonlóak voltak. Mindössze két kérdésnél volt megfigyelhető szignifikánsan eltérö eredmény a két csoport között. Ezen kívül a magyar hallgatók sok esetben ódzkodtak az „extrém” válaszoktól 
(„teljes mértékben egyetértek”, vagy „egyáltalán nem értek egyet”), míg külföldi társaik esetében ilyen trend nem volt megfigyelhető.

A felmérés első szakasza az órákon belüli munkaformákkal volt kapcsolatos. A két hallgatói csoport válaszaiban nem mutatkoztak nagy különbségek, mind a magyar (63\%), mind pedig a külföldi hallgatók (50\%) úgy vélték, hogy egy csendesebb környezetben hatékonyabban tudnak tanulni. Egyértelmü preferencia mutatkozott az órákon való aktív részvétel kapcsán is mind a két csoport körében, a magyar hallgatók 49\%-a, a külföldiek 57\%-a érezte úgy, hogy hatékonyabban tud dolgozni egy gyakorlatorientált órán, amelynek nem csak passzív résztvevője. Az órákon belüli szigorú légkör nem volt túl népszerü egyik hallgatói csoportban sem: a magyar hallgatók mindössze $13 \%$-a, külföldi társaiknak pedig $17 \%$-a érezte úgy, hogy egy szigorú órai légkörben könnyebben tud tanulni. Egyetlen esetben fordult csak elő az első szekcióban, hogy meglehetősen nagy eltérés mutatkozott a két hallgatói csoport választásaiban. Arra a kérdésre, hogy a nyomtatott, vagy a digitális formájú tananyagokat preferálják-e, a magyar hallgatók 66\%-a jelezte, hogy inkább a papír alapú anyagokat tartja hatékonyabbnak. Ugyanerre a kérdésre külföldi társaiknak mindössze 38\%-a válaszolt igennel, ami azt jelenti, hogy a külföldi hallgatói csoportokban a digitális tananyagok örvendenek nagyobb népszerüségnek a nyomtatott változatokkal szemben.

A kérdőív második része a tanítási folyamattal volt kapcsolatos. A magyar és a külföldi hallgatók is többségében elutasítóan nyilatkoztak a PowerPoint bemutatókról, vagy semlegesek maradtak a kérdésben (a magyar hallgatók mindössze 14\%-a, a külföldieknek pedig 23\%-a támogatta a PowerPoint prezentációkat). Kisebb különbségekkel, de határozottan támogatták a hallgatók a facilitátor-jellegü tanári attitüdöt, a magyarok 74\%a, a külföldiek 58\%-a nyilatkozott pozitívan a kérdésben. Ugyancsak pozitív volt a megítélése a tanár által feltett kérdések szükségességének is; a magyar hallgatók 76\%-a, a külföldieknek pedig 73\%-a jelezte, hogy hasznosnak tartja őket. Az esetleges hibáik javításánál mindegyik csoport az azonnali és direkt javítást preferálta (a magyarok 57\%-a, a külföldieknek pedig 67\%-a válaszolt pozitívan a kérdésre).

A felmérés utolsó szakaszában a hallgatók az általuk használt és leghasznosabbnak vélt tevékenységeket és feladatokat értékelhették, illetve sorolhatták fel. Kiemelkedően magas volt a preferencia mindkét hallgatói csoportban az órai anyagok online hozzáférhetőségének kérdésében. A magyar hallgatók 88\%-a, külföldi társaik 87\%-a jelezte, hogy hasznosnak találná, amennyiben az adott órára szükséges anyagokat teljes mértékben el tudná érni valamilyen online felületen. Egyértelmüen pozitív volt a megítélése a kérdőívben felsorolt gamifikációs elemeknek is mindkét 
hallgatói csoport körében. Amint az az 1. ábrán is megfigyelhetö, a magyar hallgatók $80 \%$-a, a külföldi hallgatók 78\%-a preferálta a Quizlet és Kahoot használatát az órák során.

1. ábra. A külföldi és magyar hallgatók preferenciái a Quizlet-tel és Kahoot-tal kapcsolatban

"Szeretem a Quizlet-et és a Kahoot-ot használni órákon."

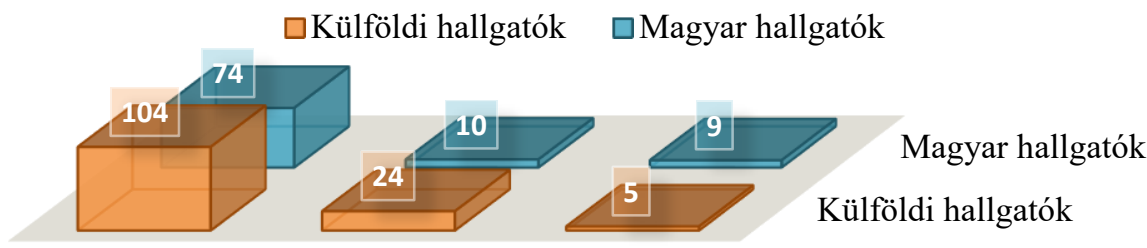

Egyetért Semleges Nem ért egyet

Ahogyan azt a 2. ábra is mutatja, a magyar hallgatók 83\%-a, a külföldieknek pedig 73\%-a vélte úgy, hogy a Quizlet hatékony segítség volt számukra a szókincs elsajátításában (az applikációt nem feltétlenül csak a szaknyelvi órákon használták).

2. ábra. A külföldi és magyar hallgatók véleménye a Quizlet-ről

"A Quizlet sokat segit a szókincs elsajátításában."

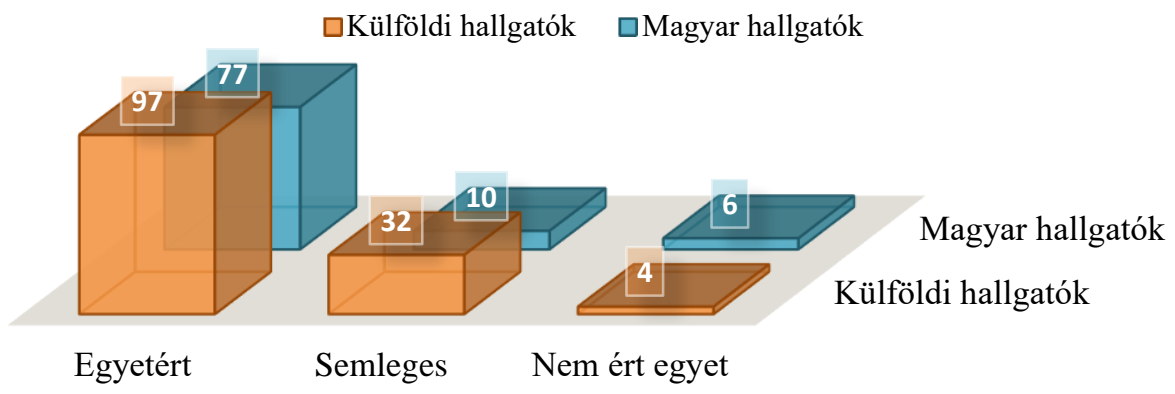

A felmérésben részt vevő külföldi és magyar hallgatók a következőképpen vélekedtek az órákon alkalmazott gamifikációs elemekröl (Quizlet és Kahoot):

„A Quizlet és más játékok megkönnyitik a tanulást órák között, vagy mondjuk hazafelé menet. Idöt spórolok vele, és sokkal könnyebb az új szókincset megtanulni.' 
„,[Szeretem használni] a Quizlet-et, hogy új szavakat és mondatokat sajátithassak el."

„A Quizlet sokat segit, hogy gyorsabban megtanuljam a szavakat.”

„A Quizlet sokat segitett a latintanulásban és az angol gyakorlásában.”

Az egyik hallgató a gamifikáció játékos oldalával kapcsolatban is kifejtette a véleményét:

„[...] az, hogy egy feladat szórakoztató, nem jelenti, hogy nem fogjuk komolyan venni."

Többen kiemelték a Quizlet nyújtotta egyik funkciónak, a szókártyáknak a hasznosságát:

„A szókártyák sokat segítettek a magyarban. Örülök, hogy a Quizletben rendelkezésre állnak [a szókártyák].'

„,Gyakran használom a szókártyákat Quizlet-ben, úgy érzem sokat segitettek nekem. A Kahoot-ot is szeretem, mert kiderül, mit tart a tanár fontosnak a szemeszter során."

„A szókártyát biztositó appok mind hasznosak.”

Az egyik magyar hallgató is hasznosnak találta a szókártyákat, azonban a digitális lehetőségek helyett inkább hagyományos módon használta őket:

„,Szókártyák! De inkább papírból csinálom öket, nem szeretem a Quizlet-es szókártyákat."

Többen említették a Quizlet és a Kahoot versenyszerü elemeit is, melyeken belül a résztvevők egymás ellen játszhatnak egyénileg vagy csoportosan. Volt olyan hallgató, akit az motivált, hogy a ranglista élére kerüljön, de nem mindenkinek volt szükséges ez az élmény ahhoz, hogy aktívan részt vegyen a feladatokban:

„Van egy párositó játék Quizlet-ben. Egy verseny. [...] Mindig addig játszom, amíg a lista élére nem kerülök. "

„[Szeretem a] Kahoot-ot, mindig utolsó vagyok, de nagyon élvezem." 


\section{Diszkusszió}

A gamifikáció során a játékszerü elemek kerülnek felhasználásra nem játékos környezetben azzal a céllal, hogy növeljék a résztvevők aktivitását és motivációját, élményszerübbé téve ezzel a tanulási folyamatot (De Sousa et al., 2014; Richards et al., 2014; Figueroa-Flores, 2015). A gamifikáció és az úgynevezett „komoly játékok” (serious games) abban különböznek, hogy az utóbbi, bár a témája komoly, alapvetően a játékélményre irányul, míg a gamifikáció célja alapvetően nem a résztvevők szórakoztatása. Bár a gamifikáció hatékonyságáról megoszlanak a vélemények, egyelőre nincsenek olyan kutatások, amelyek szerint negatív hatást fejtene ki a tanulási folyamatra (Kiryakova et al., 2014; Van Gaalen et al., 2020).

Az eredmények alapján elmondható, hogy a magyar és a külföldi orvostanhallgatók választásai között nem volt számottevő különbség a legtöbb esetben. Kiemelkedően magas preferenciát fejezett ki mindkét csoport a gamifikációra vonatkozó kérdéseknél, ami arra enged következtetni, hogy „digitális bennszülöttként” számukra nagyon fontos, hogy használhassák tanulmányi célból is a különféle technológiákat. Mindössze 18 külföldi és 12 magyar hallgató volt (a felmérésben résztvevők 13\%-a), aki figyelemelterelőnek találta a különböző hordozható eszközök használatát az órákon, a nagy többség pozitívan fogadta a lehetőséget. Mindkét csoportban többen említették, mennyire hasznosnak találták a digitális technológiák használatát a tanulási folyamat segítésére a tanórákon, valamint azokon kívül is, önálló felkészülésre vagy gyakorlásra. A kérdőív két, online elérhető platformot említett: a Quizlet-et és a Kahoot-ot. A magyar és a külföldi hallgatók is egyértelmüen pozitívan nyilatkoztak a két felület használatáról, amelyeket applikáció formájában a hordozható készülékeiken is el tudtak érni. Ezeket az eredményeket alátámasztják Csongor et al. kutatásai is (2018), amely esetben a hallgatók hasonlóképpen pozitívan nyilatkoztak és támogatták a Quizlet és a Kahoot használatát a tanórákon.

Deterding (2012) szerint a gamifikáció egyik legnagyobb előnye, hogy motiválja a hallgatókat, akik így aktívabban vesznek részt az egyes feladatokban. Az új oktatási trendek egyre hangsúlyosabb szerephez juttatják a tanulókat a tanulási folyamatban, ehhez pedig elengedhetetlen olyan módszerek alkalmazása, amivel a lehető legnagyobb aktivitási és motivációs szint érhető el. A játékalapú feladatoknak és gamifikációnak számos előnye van:

- egyénre szabható,

- azonnali visszajelzést kap a résztvevő, 
- aktív részvétel,

- motiváció fokozása,

- társas, többszereplös,

- fokozatosan készít fel a nehezebb feladatokra (scaffolding),

- a játékos környezetben megtanultak alkalmazása valós szituációban,

- értékelés és összehasonlítás a többi résztvevővel, versenyszellem.

A játékoknak több eleme is van ezeken kívül, amelyeket fel lehet használni az órákon, például az eredmények elismerése valamilyen formában, például plusz pontokként, amik beszámítanak a végső érdemjegybe (Pesare et al., 2016).

A gamifikáció kialakításához és sikeres alkalmazásához három alapvető szempontot szükséges figyelembe venni. Az első magának a rendszernek az átgondolása, mik legyenek a célok, valamint a szabályok. A rendszer függvényében fog változni a feladat dinamikája, ami más lesz egy kooperatív, mint egy kompetitív helyzetben. Ezek együttesen fogják meghatározni, hogy a résztvevők milyen érzésekkel szembesülhetnek a feladat végrehajtása közben, ami hatással lehet az aktivitási szintjükre, valamint a motivációjukra is (Yanes - Bououd, 2019).

A gamifikáció hatékonyan müködhet intrinzik (belső) és extrinzik (külső) motiváció által vezérelt résztvevők esetében is, mivel tartalmát tekintve a feladatok a tanulást és az előmenetelt segítik elö, ugyanakkor élvezetesek is. A gamifikáció elösegítheti a kooperatív, valamint az egymástól tanulást is (peer learning), aminek segítségével a tanulásban nagyobb hatékonyság érhető el (Richards et al., 2014; Figueroa-Flores, 2015; Singhal et al., 2019).

Werbach (2016) szerint, ahogy Polonyi és Abari (2017: 9) idézi, a következő hat lépés szükséges a sikeres gamifikációhoz. Először is meg kell határozni a célokat, amelyeket a gamifikáció segítségével kíván elérni az oktató. Másodszor át kell gondolni, mi lesz az elvárt viselkedés a résztvevőktől, valamint hogyan fogják mérni az aktivitásukat. Harmadszor meg kell határozni, kik vesznek részt a feladatban. A negyedik lépés magának a folyamatnak a kidolgozása, figyelembe véve a motivációs tényezőket, valamint azt is, hogy milyen visszajelzést fognak kapni a résztvevők. Az ötödik lépés annak az átgondolása és értékelése, hogy a feladat továbbra is élvezhetö-e, aminek elérése a gamifikáció egyik fö célja. Az utolsó lépés technikai jellegü, az oktatónak el kell döntenie, milyen technikai háttér szükséges az adott feladathoz, valamint milyen platformon és eszközön szeretné azt megvalósítani.

A gamifikáció hatékonyan alkalmazható az oktatás valamennyi szintjén és színterén, így a nyelvi órákon is (Kovács - Várallyai, 2018). 


\section{Konklúzió}

A felmérés eredményei alapján megállapítható, hogy a magyar és külföldi hallgatói csoportoknak meglehetősen hasonlóak az igényeik, elvárásaik és preferenciáik a tanulási és tanítási folyamattal kapcsolatban. Nyilvánvaló nemzeti hovatartozásbeli és kulturális eredetü különbözőségeik ellenére a két hallgatói csoport választásai szinte megegyeztek az esetek legnagyobb részében. Mindegyik csoport egyértelmüen az interaktív órákat részesítette előnyben, kifejezték igényüket a nagyobb önállóságra a tanulási folyamatban, ahol az oktató sok esetben facilitátori szerepet tölt be. Erősen pozitív volt a visszajelzés a különböző digitális eszközök és technológiák alkalmazásával kapcsolatosan is. Mind a magyar, mind pedig a külföldi hallgatók számára fontos, hogy az órai anyagokhoz hozzáférhessenek online is, ezen kívül igen népszerünek bizonyultak körükben a gamifikáció nyújtotta lehetőségek.

A gamifikációnak számos olyan pozitívuma van, amelyet az oktatók sikeresen alkalmazhatnak óráikon a hatékonyabb megértés és sikeresebb tanulási folyamat érdekében. A gamifikált feladatok lehetővé teszik a diákok motivációjának a növelését, aktív részvételre sarkallják őket. A gamifikációnak igen szélesek a felhasználási lehetőségei órákon belül, a különböző platformok és applikációk pedig akár az órákon kívül is segítséget nyújthatnak a tanulóknak. A folyamatos fejlesztéseknek köszönhetően az applikációk nagy része már hordozható készülékeken is elérhető, így az oktatóknak lehetőségük van kiválasztani nemcsak a céljaiknak leginkább megfelelö platformot, de a megvalósítás módszerét is.

Ezek az eredmények hasznosak lehetnek az orvosi szaknyelvoktatásban, valamint a felsőoktatás egyéb szakterületén dolgozó oktatók számára is mind a magyar, mind pedig a külföldi hallgatói csoportok esetében, és egyaránt alkalmazhatóak mind jelenléti, online, illetve hibrid oktatási formákban is.

\section{Hivatkozások}

Csongor, A. - Németh, T., - Hild, G. (2018): Online eszközök az orvosi szaknyelvoktatásban. In: Bocz, Zs. - Besznyák, R. (szerk.): Porta Lingua 2018. Tudásmegosztás, értékközvetítés, digitalizáció - trendek a szaknyelvoktatásban és kutatásban. SZOKOE: Budapest. 229-235

Deterding, S. - Sicart, M. - Nacke, L. - O’Hara, K. - Dixon, D. (2011): Gamification: Using game design elements in non-gaming contexts. Proceedings of the 2011 Annual Conference Extended Abstracts on Human Factors in Computing Systems. 66. 2425-2428 DOI: 10.1145/1979742.1979575 
Deterding, S. (2012): Gamification: Designing for motivation. interactions, 19. 14-17 DOI: $10.1145 / 2212877.2212883$

Figueroa-Flores, J. (2015): Using Gamification to Enhance Second Language Learning. Digital Education Review. 27. 32-54 Elérhetö online: https://files.eric.ed.gov/fulltext/EJ1065005.pdf

Kayımbaşığlu, D. - Oktekin, B. - Haci, H. (2016): Integration of Gamification Technology In Education. Procedia Computer Science. 102 DOI: 10.1016/j.procs.2016.09.460

Kiryakova, G. - Angelova, N. - Yordanova, L. (2014): Gamification in Education. 9th International Balkan Education and Science Conference At: Edirne, Turkey, Conference Paper. Elérhető online: https://www.researchgate.net/publication/320234774_GAMIFICATION_IN_EDUC ATION

Korkealehto, K. - Siklander, P. (2018): Enhancing engagement, enjoyment and learning experiences by gamification on an English course for healthcare students.

International Journal on Media, Technology and Lifelong Learning. 14/1. Elérhetö online: https://journals.hioa.no/index.php/seminar/article/view/2579

Kovács, T. - Várallyai, L. (2018): Gamifikáció, avagy a játékosítás szerepe napjainkban. International Journal of Engineering and Management Sciences. 3/3. 171-180 DOI: https://doi.org/10.21791/IJEMS.2018.3.14

Marek, E. - Németh, T. (2020): Interkulturális kompetenciák az egészségügyi ellátásban (Intercultural competence in healthcare). Orvosi Hetilap. 161. 1322-1330

Németh, T. - Csongor A. (2019): With or without you: the use of digital tools in teaching languages for specific purposes. Journal of Languages for Specific Purposes. 6. 4149

Németh, T. - Kajos, A. (2014): A How to develop the intercultural competence of Hungarian students. In: Bocz, Zs. - Besznyák, R. (szerk.): Porta Lingua 2014. Szaknyelvi regiszterek és használati színterek. SZOKOE: Budapest. 155-164

Németh, T. - Pozsgai, Gy. (2018): The Value of Local Culture at an Internationalised University. UNEECC Forum. 10. 39-51

Németh, T. - Rébék-Nagy, G. (2015): The importance of intercultural competence within health care. In: Bocz, Zs. - Besznyák, R. (szerk.): Porta Lingua 2015. A XXI. századi szakmai, szaknyelvi kommunikáció kihívásai: tanári és tanulói kompetenciák. SZOKOE: Budapest. 323-333

Organisation For Economic Cooperation And Development OECD (2019): Education at a Glance 2019. OECD Indicators. OECD Publishing: Paris. 228-244 Elérhető online: https://www.oecd-ilibrary.org/docserver/f8d7880den.pdf?expires $=1600596136 \& \mathrm{id}=\mathrm{id} \&$ accname $=$ guest $\&$ checksum $=825676 \mathrm{~B} 6 \mathrm{~A} 3354$ DF1CBA0C5EC7F7EE346

Pesare, E. - Roselli, T. - Corriero, N. - Rossano, V. (2016): Game-based learning and Gamification to promote engagement and motivation in medical learning contexts. Smart Learning Environments. 3. DOI: 10.1186/s40561-016-0028-0.

Polonyi T. - Abari, K. (2017): A Gamifikáció Motivációs Eszközei a Nyelvoktatásban. Debreceni Egyetem, Pszichológiai Intézet, MTA-DE Idegen Nyelvi Oktatás Kutatócsoport. Belső tanulmány. Elérhető online: http://inyelv.unideb.hu/files/belso tanulmanyok/a gamifikacio.pdf

Pozsgai, G. - Kajos, A. - Németh, T. (2012): The challenges of a multicultural university environment in the area of crisis. In Komlósi, L. and Keresnyei, K. (eds.). The proceedings of the UNEECC Forum. 191-199 
Prensky, M. (2001): Digital Natives, Digital Immigrants. On the Horizon. Lincoln: NCB University Press. Elérhető online: https://marcprensky.com/writing/Prensky\%20\%20Digital\%20Natives, \%20Digital\%20Immigrants\%20-\%20Part1.pdf

Richards, C. - Thompson, C. W. - Graham, N. (2014): Beyond designing for motivation: the importance of context in gamification. In Proceedings of the first ACM SIGCHI Annual Symposium on Computer-human Interaction in play. Association for Computing Machinery: New York. 217-226 DOI: https://doi.org/10.1145/2658537.2658683

De Sousa Borges, S. - Durelli, V. H. S. - Macedo Reis, H. - Isotani, S. (2014): A systematic mapping on gamification applied to education. In Proceedings of the 29th Annual ACM Symposium on Applied Computing. Association for Computing Machinery: New York. 216-222 DOI: https://doi.org/10.1145/2554850.2554956

Singhal S. - Hough J. - Cripps, D. (2019): Twelve tips for incorporating gamification into medical education. MedEdPublish. 8/3. 67 DOI: https://doi.org/10.15694/mep.2019.000216.1

Van Gaalen, A. E. J. - Brouwer, J. - Schönrock-Adema, J. et al. (2020): Gamification of health professions education: a systematic review. Advances in Health Sciences Education. DOI: https://doi.org/10.1007/s10459-020-10000-3

Werbach, K. (2016): Gamification. Elérhető online: https://www.coursera.org/learn/gamification

Yanes, N. - Bououd, I. (2019): Using Gamification and Serious Games for English Language Learning. International Conference on Computer and Information Sciences (ICCIS). Sakaka, Saudi Arabia. 1-6 DOI: 10.1109/ICCISci.2019.8716451

\section{Internetes hivatkozások}

UP (2020). Elérhető: https://international.pte.hu/about_university_pecs . Letöltve: 2020.12.28.

UPMS (2020). Elérhetö: https://aok.pte.hu/en/menupont/468 . Letöltve: 2020.12.28. 